\title{
SENTIDOS DA CRISE: LITERATURA E PROCESSOS SOCIAIS EM FOGO MORTOE CIDADE DE DEUS
}

\author{
Mariana Miggiolaro Chaguri e \\ Mário Augusto Medeiros da Silva
}

Fiquei encantado com Balzac, Dostoievski, aí tem o Marçal Aquino, o Mauro Pinheiro [...] Tem Guimarães Rosa, Lima Barreto, Machado de Assis. José Lins do Rego tem o Fogo morto, esse livro é de uma poesia... É tripartido, eu fiz tripartido, são três histórias, eu copiei esse livro, roubei. Só que botei na versão urbana. Recomendo aqui assim: antes de ler o Cidade de Deus, leia Fogo morto. (Paulo Lins apud Amaral, 2003, P. 35)

É ideia antiga que as obras literárias, independentemente dos tempos, conversem entre si, influenciando-se, numa comunidade imaginada. Direta ou vagamente, na história da literatura, articula-se a identificação de parentesco entre obras, ramificações entre movimentos ou escolas, filiações entre autores que, não raramente, jamais tiveram oportunidade de se conhecer e efetivamente conversar.

$\mathrm{O}$ estatuto de equivalência entre escritores diferentes está dado por seu ofício comum: a arte de escrever e criar mundos ficcionais. O conflito temporal, estilístico e social fica temporariamente suspenso. De certa maneira, como no 
poema "Procura da poesia", de Carlos Drummond de Andrade, "penetra[-se] surdamente no reino das palavras". Será aí, então, partindo e permeados por elas, nesse reino, que escritores estabelecerão relações e filiações, críticos e leitores debaterão, entrelaçando-se naquela comunidade referida.

Esse preâmbulo visa introduzir o problema que se discutirá neste artigo: as possíveis relações existentes entre dois autores brasileiros, viventes de tempos e espaços muito diferentes, estranhos pessoalmente um ao outro, José Lins do Rego (1997 [1943]), com Fogo morto, e Paulo Lins (1997), com Cidade de Deus. A sugestão da filiação e parentesco literário, no entanto, foi aventada pelo segundo - e não raras vezes -, a exemplo da epígrafe citada, em entrevista à revista Caros Amigos (Amaral, 2003, p. 35). José Lins do Rego, falecido em 1957, aos 56 anos, jamais conheceu Paulo Lins, nascido em 1958, estreante em 1997. Todavia, este afirma, em entrevistas concedidas e encontros literários, que seu Cidade de Deus é, 170 em muito, devedor e próximo do propósito, estruturas, construções de personagens e da atmosfera criada em Fogo morto.

Qual o sentido dessa aproximação? Para além da comparação estrutural e internalista de ambos os romances, questionar acerca do ponto de toque entre os dois tenciona, também, discutir os aspectos socialmente possíveis dessa convergência. Estamos questionando se processos sociais distintos e formalizações estéticas aparentemente equivalentes possuem, de fato, pontos de contato, continuidades ou rupturas, explicativos ou ilustrativos da realidade que os moldou e que os achega. Em outras palavras, há a possibilidade do paralelismo histórico e literário possuir algum tangenciamento explicativo?

Embora soe banal, somente o presente pode acionar o passado. Quando o faz, no entanto, não é uma operação sociologicamente inocente. O sentido do acionamento é o que cabe ser questionado. Nos casos de José Lins do Rego e Paulo Lins, partimos da hipótese de que suas narrativas 
ficcionais e origens sociais tenham início em processos de crise social, onde um mundo antigo dá lugar a uma nova ordem, reordenando sujeitos e posições, valores e lugares. Identificamos os eventos históricos da Abolição e da República, ocorridos respectivamente em 1888 e 1889 como pontos iniciais de desabrigamento de poder e lugar social para os dois grupos. Retomaremos essa discussão mais adiante.

\section{Estatuto da comparação}

Tratando seriamente a sugestão de Paulo Lins, que foi timidamente estudada por sua fortuna crítica $^{1}$, resolvemos explorar possibilidades comparativas entre sua obra e a do romancista paraibano. Como afirmou o autor de Cidade de Deus, "A ideia de escrever em linguagem coloquial, extensa, local, de gíria, da favela... veio muito mais do José Lins do Rego que do Guimarães Rosa [...] O mestre Zé Amaro [...] é um livro que é basicamente em cima de diálogos [...] que é o meu forte também [...]" (Silva e Costa, 2007).

Existem mais diferenças que semelhanças entre Fogo morto e Cidade de Deus, bem como entre os processos de consagração de seus autores, as relações sociais construídas por ambos interna e externamente ao sistema literário. De início, isso se torna problemático, caso se considere que os pontos de tangência são sempre mais interessantes que os paralelismos.

Todavia, ladeando-se os processos sociais narrados e os mundos ficcionais em tela, acreditamos obter boas hipóteses para discutir aspectos da sociedade brasileira republicana desde dentro, isto é, oriunda de autores cuja filiação a seus grupos sociais de origem é - e foi continuamente - autorreferenciada ou identificada pela crítica como elementos consagradores ou defeituosos (por não haver descolamento).

\footnotetext{
${ }^{1}$ Para além da entrevista citada e de sugestões em outras entrevistas do autor, aproximações entre os autores de Fogo morto e Cidade de Deus podem ser encontradas em Vargas (2009) e Mello (2008).
} 
Estabeleçamos, arbitrariamente, como parâmetros comparativos, destarte, (1) a temporalidade interna das obras; (2) as figurações de seus narradores; (3) as relações de seus personagens entre si; (4) a consciência do processo da crise social pelos personagens; (5) e, por fim, o uso social que o passado possui em ambas as obras, tomando a memória coletiva como um ponto de apoio a essa discussão.

Esses cinco pontos se justificam de maneira articulada: o uso do tempo em ambos os romances - a rapidez ou morosidade das cenas, da descrição ou narração - pode ser explicativo do lugar ocupado pelo narrador, de que grau de inteligibilidade ou desfaçatez do processo social ele é capaz de ter/enunciar.

Muito pode ser dito, em ambos os trabalhos, acerca das relações internamente construídas entre os personagens (dependência ou independência; previsibilidade ou imponderável; senhores e servos; malandros e otários), indicando uma organi-

172 cidade ou rarefação da vivência sócio-histórica, a desembocar na consciência da enunciação, acerca dos efeitos da crise social original, identificados em dois momentos históricos precisos.

Abolição e República instauram a nossa modernidade, de maneira incompleta e desigual, extremamente violenta e arbitrária, condicionando, assim, a maneira como os grupos sociais se relacionarão com uma memória coletiva daqueles processos e suas decorrências. Para uns, a memória é o ponto de partida da inteligibilidade do lugar social; para outros, é o que resta e tem de ser recuperado e reavivado.

Em meio a esses pontos, fica a discussão sobre a sociedade envolvida, para além dos universos do engenho em decadência ou das favelas em decomposição. O que podem nos dizer os narradores e personagens de ambas as obras sobre isso? De que linguagem se valerão para enunciar seu lugar socialmente imposto ou construído? Que papel histórico desem- 
penha o Estado e outros agentes sociais com tais grupos, em seus espaços sociogeográficos?

Em Mimesis (1994 [1946]), Erich Auerbach argumenta que a literatura ocidental é composta por diferentes modalidades de realismo forjadas na capacidade de reconhecimento, por parte do autor e de seu público, daquilo que ocorre na profundidade da vida cotidiana. Assim, diferentes modos e graus de problematicidade, seriedade e tragicidade na obra literária estão intimamente relacionados aos limites da consciência histórica, os quais, por sua vez, dizem respeito à capacidade de percepção das forças históricas; percepção esta que depende, finalmente, do grau de reconhecimento da dramaticidade e problematicidade do domínio da vida cotidiana. "Quanto maior o reconhecimento, maior a consciência histórica, e correspondentemente mais profundo, sério e problemático o realismo" (Waizbort, 2007, p. 309).

Analisando simultaneamente, forma literária e processo social, Auerbach observa que, no romance moderno, o escritor renunciou a uma narrativa baseada no transcurso temporal totalizado, o que teria implicado a fragmentação da narrativa. Entretanto, tal fragmentação inscreveria em si a chave para visão do todo: "o todo é, portanto, uma questão de atitude do escritor com relação à realidade do mundo que ele apresenta" (Auerbach, 1994 [1946], p. 497).

Fogo morto e Cidade de Deus encerram em suas estruturas narrativas essa renúncia e constroem um interessante jogo de espelhos entre ficção e realidade como modo de tornar inteligível a decadência dos engenhos de cana-de-açúcar e a experiência social das classes baixas, respectivamente. Se o todo é uma questão de atitude do escritor em relação ao mundo, é importante observar que, no caso de Fogo morto e Cidade de Deus, as diferenças entre os processos sociais implicam diferenças narrativas importantes, embora revele pontos de toque interessantes. 


\section{Uma estrada, três casas ${ }^{2}$}

Última obra do ciclo da cana-de-açúcar, Fogo morto mostra a decadência do engenho Santa Fé e de seu senhor, coronel Lula. Em romances anteriores, José Lins do Rego reconstrói a história de outro engenho, o Santa Rosa, de propriedade do coronel José Paulino, utilizando uma narrativa linear, que é quebrada justamente em Fogo morto, cuja narrativa é construída pelo entrelaçamento de temporalidades diversas, evidenciando a quebra do processo social e histórico comentado anteriormente ${ }^{3}$.

A estrutura de Fogo morto está assentada no contraponto entre a estrada que liga o engenho Santa Fé à vila do Pilar, oferecendo, também, acesso ao Santa Rosa e às casas do coronel Lula de Holanda, do mestre seleiro José Amaro e do capitão Vitorino Carneiro da Cunha ${ }^{4}$. Casas mais ou menos desestruturadas, perto da falência ou da loucura, ligadas por uma estrada que serve de caminho para 174 senhores e moradores de engenho, comerciantes, mestres de ofício e cangaceiros em percursos que, pouco a pouco, apresentam ao leitor os personagens e os dilemas de um universo em ruínas.

Ruína que, no caso do Santa Fé, é marcada de modo decisivo pela Abolição. Em 13 de maio de 1888, todos os

\footnotetext{
2 Partes desta seção encontram-se em Chaguri (2012).

${ }^{3}$ Deve-se notar, contudo, que a decadência do Santa Fé é contemporânea ao triunfo do Santa Rosa, de modo que, a despeito da ruína de um senhor de engenho, todos os outros, e particularmente José Paulino, continuam desempenhando o papel social reservado ao patriarca, ponto de partida para o equilíbrio dos conflitos e dos impasses, ainda que, no entanto, a figura de José Paulino opere como ponto de reequilíbrio dos conflitos narrados. Para um estudo que explora a temporalidade compartilhada entre Fogo morto e Menino de engenho, ver Fonseca (2001).

${ }^{4}$ A ideia de que a casa e a estrada representam focos narrativos distintos mas complementares é sugerida por Raymond Williams (1989). No caso de Fogo morto, Franklin Thompson (1957, p. 5) observa que a estrada onde mora mestre Amaro pode ser tomada como o eixo que constrói a narrativa: "há uma estrada-tronco que atravessa Fogo morto como um fio condutor, ligando as três partes do livro num todo harmonioso. Ao longo dessa estrada passam todos os personagens dessa história”.
} 
escravos abandonaram o engenho ${ }^{5}$ e Lula teve seu primeiro acesso de loucura. O cotidiano passa a se impor como um drama num engenho com o eito quase deserto e a casa-grande entregue à monotonia de uma família ensimesmada, avessa ao convívio com os vizinhos ou com a gente do Pilar e, cada vez mais, sem lugar no mundo (cf. Lins do Rego, 1997 [1943], pp. 236-40).

É nessa rotina de dias iguais, no interior de um engenho que, a duras penas, continua produzindo pequenas quantidades de açúcar, que a casa do mestre José Amaro torna-se decisiva não apenas para a dinamização da narrativa, como também para a compreensão dos elementos em disputa num lento processo de decadência de casas, famílias e engenhos de açúcar. Na beira da estrada onde vive o mestre seleiro, a autoridade do senhor de engenho do Santa Fé é questionada e enfrentada, bem como outros modos de hierarquização social são imaginados e, vez por outra, experimentados.

Oficial de beira de estrada, morador de engenho que vive como se fosse dono da terra, sem pagar foro, livre, portanto, do arbítrio do senhor, condição que garante a José Amaro autonomia capaz de afiançar sua condição de senhor de suas escolhas, de seu tempo e de seu trabalho: "- sou pobre [...] mas não faço vergonha aos pobres [...] aqui nesta minha porta tem passado gente rica, gente lorde, pra me convidar para isto e aquilo. Não quero nada. Vivo de cheirar sola, nasci nisto e morro nisto" (Lins do Rego, 1997 [1943], p. 35).

Um homem pobre, que vive de seu trabalho e, portanto, faz justiça aos pobres. É justamente a possibilidade de escolher como e para quem trabalha o ponto capaz de lhe

\footnotetext{
5 "Os negros do Santa Fé se foram para os outros engenhos. Ficara somente com seu Lula o boleiro Macário, que tinha paixão pelo ofício. Até as negras da cozinha ganharam o mundo" (Lins do Rego, 1997 [1943], p. 232). Importa notar que a fama de Lula como um senhor cruel e injusto com os escravos gera inúmeras dificuldades para a contratação de mão de obra após a Abolição.
} 
garantir o livre-arbítrio e, consequentemente, a afirmação de sua igualdade para com os senhores. Enquanto o pintor Laurentino segue para o trabalho no Santa Rosa, o seleiro se distingue do interlocutor afirmando que:

- [...] estas mãos que o senhor vê nunca cortaram sola para ele [José Paulino]. Tem a sua riqueza, e fique com ela. Não sou criado de ninguém. Gritou comigo, não vai.

- Grita, mas é bom homem, mestre Zé.

- Eu sei. A bondade dele não me enche a barriga. Trabalho para homem que me respeite. Não sou um traste qualquer. (Lins do Rego, 1997 [1943], p. 35).

São conversas como esta, de beira de estrada, travadas com mestres de outros ofícios ou moradores de engenho da região, que apresentam ao leitor a percepção de José Amaro sobre o mundo ao redor, reconstruindo a dominação

176 patriarcal de um ponto de vista até então inédito no ciclo da cana-de-açúcar: o do dominado.

É, por exemplo, numa prosa com um portador do engenho do Oiteiro, que seguia para o Pilar com recado do senhor de engenho para o delegado, que mestre Amaro evidencia o jogo de forças no qual todos ali estavam envolvidos e, ao mesmo tempo, imagina outra ordem:

- Este Ambrósio [delegado] é um banana. Queria ser delegado nesta terra, um dia só. Mostrava como se metia gente na cadeia. Senhor de engenho na minha unha não falava de cima para baixo.

- Seu Augusto [senhor de engenho do Oiteiro] não é homem para isto, mestre Zé.

- Homem, não estou falando de seu Augusto. Estou falando é da laia toda. Não está vendo que, comigo delegado, a coisa não corria assim? Aonde já se viu autoridade ser como criado, recebendo ordem dos ricos? Estou aqui no meu 
canto. Mas estou vendo tudo. Nesta terra só quem não tem razão é pobre.

(Lins do Rego, 1997 [1943], p. 41).

Ainda que a oposição entre ricos e pobres esteja presente em outros romances do ciclo, o mestre evidencia outro aspecto igualmente relevante: a extensão de práticas privadas para a esfera pública, num movimento que torna o poder de mando dos senhores extensivo às autoridades legalmente constituídas, criando um universo no qual as posições sociais são claramente definidas e, dificilmente, intercambiáveis. Assim, mestre Amaro apresenta a si mesmo como um pobre que conhece o seu lugar ${ }^{6}$.

Com o passar do tempo, a afirmação de autonomia do mestre seleiro, bem como seu permanente questionamento da ordem social estabelecida no engenho acabam por conduzi-lo a uma solidão que não consegue explicar, mas que o leva a andar pelas noites "estrada afora", num desejo de "estar só, viver só, sentir tudo só. A noite convidava-o para andar" (Lins do Rego, 1997 [1943], p. 61). Na manhã seguinte, "corria por toda parte que o mestre José Amaro estava virando lobisomem” (p. 61).

Àquela altura, o mestre era um eleitor que votaria contra José Paulino, o poderoso vizinho do Santa Fé, um homem - José Amaro - que viraria lobisomem à noite e, finalmente, um morador que falaria mal da família da casa-

\footnotetext{
${ }^{6}$ José Amaro aponta a principal diferença entre ele e o compadre Vitorino Carneiro da Cunha "um pobre com chaleirisimo [...] cabra muito sem vergonha, atrás dos grandes, como cachorro sem dono" (Lins do Rego, 1997 [1943], p. 45). Padrinho de Luís, filho de Vitorino, descontentava o mestre o fato de o compadre não compreender seu lugar na hierarquia social, transitando pelo mundo dos ricos em busca de favores e condescendência. Vitorino, por sua vez, não se via como igual ao mestre, antes localizava a si mesmo como alguém em condições de igualdade com José Paulino: “- [...] Sou homem branco como o José Paulino. É meu primo [...] Não esteja pensando que sou um camumbembe [...]” (p. 51). A ascendência familiar é mobilizada, então, para reposicionar a hierarquia social, acionando um sobrenome em oposição à condição material de seu núcleo familiar.
} 
-grande, suposições que, pouco a pouco, fazem do mestre uma figura mal vista por todos. Conforme as histórias se espalham, corre o boato de que o senhor de engenho pediria a casa em que o mestre vivia, e Sinhá, esposa de José Amaro, é a primeira a se dar conta do risco que corriam, compreendendo que a família estava na iminência de perder tudo aquilo que reconhecia como seu: "aquela era a sua casa, aquelas as suas flores, tudo aquilo ela tinha como coisa de sua existência. Veio-lhe um amor desesperado por tudo" (p. 148).

Não demorou muito para que o mestre fosse intimado a comparecer à audiência com o senhor de engenho. O diálogo entre o morador e o senhor instaura a hierarquia que, até então, o mestre julgava alheia a ele:

- Muito boa tarde, coronel Lula.

O velho baixou os olhos vidrados para cima dele,

178 procurando reconhecê-lo.

- Hein, é o senhor José Amaro, hein?

- Sim, sinhô, coronel, sou eu mesmo.

[...]

- Quem é que manda neste engenho, hein, mestre José Amaro? De quem é esta terra, hein, mestre José Amaro?

- O senhor sabe melhor do que eu, coronel.

[...]

- Hein, mestre José Amaro, eu mandei chamá-lo para saber de coisas que o senhor anda dizendo, hein?

- Coronel, eu não sei de nada. Vivo na minha casa, do meu trabalho.

- Quem manda nesta terra, hein, mestre José Amaro?

- Quem manda é o senhor do engenho.

- Mando eu, hein, mestre José Amaro?

$[\ldots]$

- Já lhe disse, mestre José Amaro, procure outro engenho. Quem manda, aqui, hein, mestre José Amaro? 
O mestre baixou a cabeça.

E foi se retirando.

(Lins do Rego, 1997 [1943], p. 109).

Apesar de ser um senhor recluso, pouco afeito à rotina do engenho - entregue às ordens do feitor e de dona Amélia -, Lula não se esquiva de afirmar a legitimidade de seu poder de mando dentro de seus domínios, desempenhando o pleno arbítrio sobre sua propriedade e, particularmente, sobre quem a habita. No jogo entre a legitimidade do senhor e a fraqueza social do mestre se constrói o lugar social de ambos, num processo que desestabiliza as certezas que até então José Amaro possuía, dado que “[...] não podia compreender que tivesse sido jogado para fora do Santa Fé. Aquela casa tinha sido do seu pai, onde nascera, onde aprendera seu ofício, seria de outro, somente porque um negro mexeriqueiro fizera uma intriga" (p. 177). Perplexidade que é compartilhada pelo caçador Manuel da Úrsula, que, em conversa à beira da estrada com o mestre, reflete: “- [...] O senhor não matou, o senhor não roubou, e chega um doidela deste e sacode o senhor para fora de um sítio que vem de seu pai [...] Eu não posso dar conselho ao senhor, o senhor é homem velho, mas eu não saía. Deve haver algum direito" (p. 178; grifo nosso).

Sentindo-se humilhado, um "homem odiado por todos, fazendo medo aos meninos, assombrando as mulheres [...] e para desgraça maior, posto para fora da casa que seu pai fizera somente porque um negro ordinário fora inventar mentiras para um senhor de engenho de miolo mole" (p. 283), a situação do mestre começa a ser revertida quando, na estrada, encontra um comboio de aguardente liderado por Alípio, a quem revela o drama que vivia. A sorte de José Amaro ganha, então, novos contornos e a possibilidade de garantir algum direito lhe parece menos absurda: "- Pois mestre, eu lhe digo uma coisa: não saia. Este velho vai ver a 
força do capitão. Não saia. Estou chegando do Ingá. A cama do tenente Maurício está preparada. Mande este velho à merda" (p. 177).

Alípio se refere ao capitão Antônio Silvino, cujo bando de cangaceiros estava na região, em fuga da força volante liderada pelo tenente Maurício. Em algumas ocasiões, Alípio havia se valido dos serviços do mestre para o conserto de arreios, para a compra de mantimentos para o bando, bem como para atualizar informações sobre os deslocamentos da tropa do tenente. Ao auxiliar o bando, mesmo que a distância e de maneira pontual, recebe a proteção do capitão e, tempos depois, Lula recebe um bilhete de Antônio Silvino, solicitando que José Amaro não seja incomodado (cf. Lins do Rego, 1997 [1947], pp. 297-98). O mestre, por sua vez, não parecia inclinado a, até aquele momento, resistir à ordem do senhor, pelo contrário, avaliava que Lula era o dono da terra e "porque é dono, manda do jeito 180 que quer” (p. 287). Contudo, o arbítrio do senhor podia ser questionado por Antônio Silvino e, recebendo a proteção do cangaceiro, José Amaro permanece na terra, recusando oferta de José Paulino para se mudar para um engenho seu no Itambé, afinal, "tinha ordem para não sair. Não disse de quem era a ordem, mas o velho sabe de quem é” (p. 326) ${ }^{7}$.

Além de se sentir protegido, a intervenção de Antônio Silvino permite ao mestre reestabelecer sua classificação social sobre homens e coisas, de modo a minimizar a possível expulsão e transformar uma eventual saída num ato de vontade própria: "qualquer dia deste arrumo os meus troços e me mudo. Estou perto da morte. E mesmo a minha

\footnotetext{
${ }^{7}$ Como sintetiza o mestre: "Aquele Lula de Holanda, sem que nem mais, mandava que ele fosse de uma casa que o pai levantara. Anos e anos perdidos. E Manuel de Ursula vinha lhe falar em direito. Pobre não tinha direito. Quem sabia dar direito aos pobres era o capitão [Antônio Silvino], era Jesuíno Brilhante, era o cangaço que vingava, que arrasava um safado como Quincas Napoleão" (Lins do Rego, 1997 [1947], p. 281). Antônio Silvino, figura verídica do cangaço, atuou com seu bando no sertão da Paraíba e de Pernambuco entre 1896 e 1914.
} 
mulher está querendo ir morar lá para as bandas da Paulista, para ficar mais perto da filha” (p. 326).

Se o bilhete de Antônio Silvino acalma o mestre, coloca dona Amélia em desespero, pois fazia do marido um caso inédito por ali: "um senhor de engenho sem força para mandar na sua terra" (pp. 322-23).

Ao longo da narrativa de Fogo morto, todos os personagens se apresentam ao leitor com a indicação do lugar social que ocupam naquele universo, cabendo a José Paulino, o mais rico senhor de engenho da várzea, a função de reequilibrar a ordem e a hierarquia quando estas são abaladas. $\mathrm{O}$ cangaceiro Antônio Silvino e o sonhador Vitorino Carneiro da Cunha são os únicos personagens capazes de transitar entre todos os espaços dessa rígida hierarquia, costurando, vez por outra, situações capazes de salvaguardar os direitos dos pobres. Para o mestre Amaro, o cangaceiro "tinha força para botar as coisas nos seus lugares" (p. 284), o que, num contexto marcado por relações sociais assimétricas, afirma a violência como mediação privilegiada.

A desestabilização do universo dos engenhos narrada em Fogo morto figura conflitos que se tornaram estruturais, ou seja, interesses políticos, econômicos e sociais não conseguem mais se fazerem representar como gerais, e, progressivamente, diferentes grupos sociais reivindicarão tanto participação política como direitos sociais.

Nesses termos, José Amaro pode ser particularizado como o personagem que percebe a alteração do jogo de forças, enxergando o processo com uma lucidez que o leva ao suicídio, afinal, ainda que o arbítrio do senhor pudesse ser questionado pelo cangaceiro Antônio Silvino, e apenas por ele, a legitimidade do senhor permanece sendo reconhecida pelo mestre, de modo que, ao lutar por direitos, a desigualdade de forças torna-se patente.

Desse modo, a decadência perpassa todas as esferas do engenho Santa Fé, desalojando todos os personagens de 
seus papéis sociais, agora, todos são vítimas da mesma tragédia: ou morre ou enlouquece.

\section{Mosaico de vidas breves ${ }^{8}$}

Cidade de Deus, o conjunto habitacional, agudiza a imagem do lugar social dos pobres e negros ser o do Quarto de despejo, como o descreveu Carolina Maria de Jesus em sua obra homônima publicada em 1960. Solução governamental improvisada para as enchentes de 1966, para onde foram movidos os flagelados de diferentes regiões do Rio de Janeiro, como medida temporária - que se tornaria perene - à falta de moradia. Lugar de memórias desencontradas e sonhos interrompidos, apresentados inicialmente ao leitor pelos olhos de dois personagens infantis - Buscapé e Barbantinho -, num braço do rio que corta o conjunto, onde trafegam águas ora silenciosas, ora caudalosas, às vezes límpidas, palco de brincadeiras, lavagens, servindo

182 também para extração de sustento, e por vezes rubras, sujas de excrementos, detritos, sangue e corpos desovados, como à ocasião em que Buscapé e Barbantinho se encontram. As águas trouxeram todos àquele lugar, criador de lendas, peripécias e desventuras, que foi e continuaria sendo mítico pelos mais diversos motivos ao longo da trama.

Antigamente a vida era outra aqui neste lugar onde o rio, deixando o coração bater em pedras, dando areia, cobrad'água inocente, risos líquidos e indo ao mar, dividia o campo em que os filhos de portugueses e da escravatura pisaram. [...] Um dia essas terras foram cobertas de verde com carro de boi desafiando estradas de terra, gargantas de negros cantando samba duro, escavação de poços de água salobra [...] Cidade de Deus deu a sua voz para assombrações dos casarões abandonados, escasseou a

\footnotetext{
${ }^{8}$ Partes desse texto foram utilizadas em Silva (2011, 2013).
} 
fauna e a flora, remapeou Portugal Pequeno e renomeou o charco: Lá em Cima, Lá na Frente, Lá Embaixo, Lá do Outro Lado do Rio e Os Apês. [...] Os novos moradores levaram lixo, latas, cães vira-latas, exus e pombagiras em guias intocáveis, dias para se ir à luta, soco antigo para ser descontado, resto de raiva de tiros, noites para velar cadáveres, resquícios de enchentes, biroscas, feiras de quartas-feiras e as de domingo, vermes velhos em barrigas infantis, revólveres, orixás enroscados em pescoço, frango de despacho, samba de enredo e sincopado, jogo do bicho, fome, traição, mortes [... $]^{9}$ (Lins, 1997, pp. 16-18).

Abre-se assim uma paisagem aparentemente aleatória e desordenada - Lá em Cima, Lá Embaixo, Lá na Frente, Lá do Outro Lado do Rio, Os Apês, A Praça da Loura, A Rua do Meio, A Treze - por onde os moradores fluem com bastante precisão e conhecimento, numa miríade de surgimentos e desaparições de personagens impressionante.

Cidade de Deus ${ }^{10}$, o romance, como bem frisou Roberto Schwarz (1999), é um "catatau de quinhentas e cinquenta páginas" ${ }^{11}$, repartido em três partes - A História de Cabeleira,

\footnotetext{
${ }^{9}$ O autor continua: “[...] jesus cristos em cordões arrebentados, forró quente para ser dançado [...] pobreza para querer enriquecer, olhos para nunca ver, nunca dizer, nunca, olhos e peito para encarar a vida, despistar a morte, rejuvenescer a raiva, ensanguentar destinos, fazer a guerra e ser tatuado [...] Levaram também as pipas, lombo para polícia bater, moedas para jogar porrinha e força para tentar viver. Transportaram também o amor para dignificar a morte e fazer calar as horas mudas" (Lins, 1997, p. 18).

${ }^{10}$ Utilizamos aqui a primeira edição do livro, publicada em 1997, antes das polêmicas envolvendo verossimilhança e requisição de pagamento de supostos direitos a pessoas cujos nomes e histórias teriam sido utilizados por Paulo Lins; ou ainda, passagem do romance para o cinema, por Kátia Lund e Fernando Meirelles, em 2002, o que tornou o romance mundialmente conhecido, tendo o autor feito a opção de modificar nomes de personagens (para não ser alvo de processos) e reduzir significativamente as páginas de sua narrativa original, bem como alterar expressões do livro para facilitar a tradução e circulação internacional.

11 "O romance de estreia de Paulo Lins, um catatau de quinhentas e cinquenta páginas sobre a expansão da criminalidade em Cidade de Deus, no Rio de Janeiro, merece ser saudado como um acontecimento. O interesse explosivo do assunto,
} 
A História de Bené e A História de Zé Pequeno - compondo, em nossa interpretação, um mosaico de vidas breves. A marca do tempo é central na narrativa: sua passagem, em Cidade de Deus, é fugidia, criando-se a interessante situação de um mundo ficcional encerrado numa paisagem conhecida e manipulada muito bem apenas pelos personagens, percorrendo estradas, ruas, blocos, passagens, becos, matas e antros sempre com sofreguidão, entre o final dos anos 1960 e início dos 1980.

Raros são aqueles que se podem demorar nessa paisagem. Entre os malandros, promotores das primeiras lendas, igualmente inusitados são os que ultrapassam os vinte e poucos anos. No mais, as vidas são breves, fugazes como os diálogos, como um movimento truncado no meio, interrompido por um olhar errado, por uma fala mais ríspida, por uma decisão imediata.

Em geral, o fim é espasmódico, oriundo de uma troca 184 de tiros, de balas perdidas, da ação policial, da violência em estado bruto, da quebra de um código de ética não escrito, mas conhecido por todos, sujeitos-homens no mundo cão ${ }^{12}$, igualando malandros e otários - os trabalhadores que ocupam as posições mais precarizadas e desprestigiadas na cidade e mesmo os policiais. Lugar onde "Falha a fala. Fala a bala" (Lins, 1997, p. 23), nos anuncia um narrador onisciente, em terceira pessoa - por vezes flertando com a primeira $^{13}-$,

o tamanho da empresa, a sua dificuldade, o ponto de vista interno e diferente contribui para a aventura artística fora do comum. A literatura no caso foi levada a explorar possibilidades robustas, que pelo visto existem" (Schwarz, 1999, p. 163).

12 “- Meu irmão, eu fumo, eu cheiro, desde nenenzim que peço esmola, já limpei vidro de carro, já trabalhei de engraxate, já matei, já roubei... Não sou criança não. Sou sujeito homem!" (Lins, 1997, p. 410).

${ }^{13}$ Como no trecho donde se extraiu a citação: "Poesia, minha tia, ilumine as certezas dos homens e os tons de minhas palavras. É que arrisco a prosa mesmo com balas atravessando os fonemas. É o verbo, aquele que é maior que o seu tamanho, que diz, faz e acontece. Aqui ele cambaleia baleado. Dito por bocas sem dentes e olhares cariados, nos conchavos de becos, nas decisões de morte. A areia move-se nos fundos dos mares. A ausência de sol escurece mesmo as matas. O líquido-morango do sorvete mela as mãos. A palavra nasce no pensamento, desprende-se dos 
sem lugar definido naquela paisagem, observador participante e distante ao mesmo tempo; sem moral precisa, que entende muito bem o que acontece no seu entorno e o narra, sem espanto, comiseração, nojo ou falsa piedade.

É um narrador que também sabe onde e por que tudo começou. E é por isso que as três histórias que vertebram o livro organizam a narrativa do ponto de vista da memória. Cabeleira, Bené e Zé Pequeno atravessam aquela temporalidade exígua - anos 1960 a 1980 -, tendo seus feitos contados como se fossem uma epopeia. Mas é difícil afirmar que sejam heróis, embora em seu entorno se expresse uma coletividade. Ninguém é inocente em Cidade de Deus, assim como não há alguém que seja completamente malévolo. A ambiguidade constante dos personagens é um traço distintivo importante. A linha que separa malandros e otários é muito tênue.

E será nessa ambiguidade que a memória coletiva se articulará, contando as histórias dos três malandros míticos, bandidos de alta periculosidade - Cabeleira, integrante do Trio Ternura, ainda algo inocente em face do que viria depois; Bené, criado no conjunto, se tornou o bandido mais amado da favela, ao mesmo tempo que estabelece a integração entre grupos antagônicos (os bichos-soltos, bandidos e os cocotas, garotos de baile e da contracultura nos anos 1970), realçando a ambiguidade, é amigo inseparável de Dadinho; por fim, Zé Pequeno, antigo Dadinho, que, como Bené, se cria na Cidade de Deus e começa a aprender a malandragem, em idade pueril, olhando Cabeleira e outros agir. Pequeno fecha o ciclo, se tornando um bandido implacável, mortal, protagonista de uma guerra de proporções impressionantes contra o antigamente pacato morador do conjunto, Mané Galinha, e Sandro Cenoura, seu rival no tráfico de drogas.

lábios adquirindo alma nos ouvidos, e às vezes essa magia sonora não salta à boca, porque é engolida a seco. Massacrada no estômago com arroz e feijão porque a palavra é defecada ao invés de falada" (Lins, 1997, p. 23). 
A tônica é um presente contínuo e fugaz, embora o romance se estruture em três memórias delimitadas e espaços físicos específicos. Insistiremos na imagem do mosaico. Há um esforço considerável, por parte de um narrador difuso, em articular aquelas vidas breves num todo. Não se tratam de histórias fragmentadas, mesmo quando se assemelham a pequenos contos internos ao romance, elas se entremeiam, se sobrepõem, se reforçam e se esclarecem.

Assim como não nos parece possível identificar uma voz dominante, igualmente se faz difícil dizer que exista uma fragmentação narrativa a ponto de desnortear o leitor, de se tornar ininteligível. Ao contrário, a brevidade da vida, a experiência ao rés do chão das classes baixas, a futilidade de ser ou estar no mundo, a autoridade em disputa o tempo todo etc. são costuradas num esforço denso e visível, com mais ou menos sucesso, ao longo da trama.

Se o presente contínuo domina a trama, fica evidente 186 na fala dos personagens que não há espaço suficiente para o devir. Ele aparece apenas quando se pensa em meter a boa, ou seja: ganhar bastante dinheiro, para poder sair daquele lugar:

Cabeleira deu bastante dinheiro para Berenice comprar as coisas que faltavam para se juntarem de vez. A mulher passou a semana pedindo ao marido para dar um tempo com essa vida de crimes. Ele ainda não era fichado, podia muito bem arrumar um emprego. Queria segurança e paz para poder criar os filhos que teria com ele numa boa. Cabeleira dizia que ia continuar a meter a bronca até estourar a boa para montar um comércio grande com um monte de empregados trabalhando e ele só contando dinheiro, dando as ordens. Depois pensaria em filhos. [...] Pelé e Pará não perdiam tempo em fazer planos, somente pensavam em cinco gramas de cocaína que iriam comprar para romper o ano (Lins, 1997, p. 97). 
O sonho de meter a boa raramente se concretiza. Contudo, ele tem origem no pavor que os personagens possuem da rotina dos otários. Trabalhar para outros, sem ser devidamente valorizado; estudar, sem perspectivas de mudanças efetivas e concretas. Há uma habilidade muito grande do narrador em apresentar algumas biografias dos bichos-soltos, mostrando a tragédia de suas vidas, de suas famílias. Não se trata de determinismo social, ao contrário: a tragédia é estar no mundo e ter consciência do fracasso dessa situação. Não por acaso, vários personagens, muitas vezes os mais cruéis, sonham acordados com uma vida diferente, num intervalo de tiroteio ou guerra entre quadrilhas. Cabeleira, Bené e Zé Pequeno têm divagações preciosas nesse sentido:

O negócio era chegar à quadra do Salgueiro ou do São Carlos com uma beca invocada, um pisante maneiro, mandar descer cerveja à pamparra, comprar logo um montão de brizolas e sair batendo para os amigos [...] olhar assim para a preta mais bonita e chamar para beber um uísque, mandar descer uma porção de batatas fritas, jogar um cigarro de filtro branco na mesa [...] comprar um apartamento em Copacabana, comer filha de doutor, ter telefone, televisão, dar um pulinho nos States de vez em quando, que nem o patrão de sua tia. Um dia acharia a boa (Lins, 1997, p. 50).

Bené devorou o nhoque para ir comprar fazenda com a cocotada, decidiu que o grupo todo deveria vestir-se igual [...] Iriam a Botafogo comprar o pano. Quem faz compra no centro da cidade é pobre [...] Depois das compras iriam a Copacabana pegar um cinema e jantariam num restaurante da Gávea, onde combinariam aos risos um acampamento ou uma noite no Dancin' Days, porque a onda agora era discoteca [...] O sonho de Bené era o de comprar um terreno onde tivesse água corrente para o cultivo para ele e 
os cocotas morarem [...] Era esse o seu sonho: ganhar uma mina bonita, morar entre gente bonita e dançar discoteca até o fim da vida, numa boa. Nada daqueles crioulos com cara nervosa e sem dentes (Lins, 1997, p. 352).

- Pcom $i$ dá pi, $p$ com $a$ dá pa, pi-pa, pipa, pipa, porra! Pipa - soletrava Pequeno ao lado da mulher de seu novo parceiro em Realengo [...] Agora realizava o sonho que tomara conta dele na cadeia, pois tinha sempre que pedir a alguém para ler as cartas que recebia e isso poderia ser perigoso [...] Já sabia assinar o nome, e, se encontrasse o tal doutor Crespo, que resolvia qualquer problema, poderia ter identidade e talão de cheque, coisa que também sempre sonhara ter. (Lins, 1997, pp. 537-38).

Qualquer eufemismo ao fracasso, portanto, é sublimado. Todos os sonhos acima passam, em alguma medida, 188 por ser igualados a outros em aspectos de uma cidadania republicana (não no sentido clássico, mas deturpada): ter registro ou identidade civil, ser proprietário, para ter poder de compra e mando. Não se trata de emancipação humana, igualdade fraternal e liberdade existencial. Para os três malandros míticos, nenhum desses sonhos se realizaria.

O mesmo vale para a imensa maioria de malandros, bichos-soltos, cocotas ou otários que povoam a narrativa de Cidade de Deus. A consciência do fracasso começa também pela percepção do território, da paisagem geográfica, explicativa da conformação dos destinos, do trato cotidiano, da visão exterior sobre o que os personagens eram, são ou jamais poderiam ser. É Zé Pequeno quem expressa isso claramente, depois de matar seis chefes locais do tráfico e se tornar, ao lado de Bené, dono de Cidade de Deus, juiz, executor, senhor da vida e da morte local. Para ele, não há eufemismos, não há meio-termo sobre a realidade e o que fazer estando nela: 
O pensamento voltou a correr pelas ruas do conjunto, entrava pelos becos imperativamente, parava nas esquinas fazendo pose. Porque elas eram suas, isso mesmo, era o dono da rua, o rei da rua, ali, vivo no baralho daquele jogo, o jogo de armas, de riscos, de raiva. [...] "Conjunto o quêe? Favela! Isso mermo, isso aqui é favela, favelão brabo mermo. Só o que mudou foi os barraco, que não tinha luz, nem água na bica, e aqui é tudo casa e apê, mas os pessoal, os pessoal é que nem na Macedo Sobrinho, que nem no São Carlos. Se é na favela que tem boca de fumo, bandido pra caralho, crioulo à vera, neguinho pobre à pamparra, então aqui também é favela, favela de Zé Pequeno." (Lins, 1997, p. 242; grifos nossos).

Não escapa também ao narrador onisciente difuso de Cidade de Deus a consciência sobre o território. Entretanto, ao refletir sobre ela, ele se questiona sobre o que legitima a violência e mantém o status quo ${ }^{14}$. Se conclui, por um lado, que a legitimidade precária da dominação parte da condição de vida dos dominados, também discute as diferentes manifestações da revolta e da consciência, seja contra a desdita dos bandidos ou à faceta mais presente do Estado que se manifesta na favela.

\footnotetext{
14 "Barracos de caixas de tomate, madeiras de lei, carnaúba, pinho de riga, caibros cobertos, em geral, por telhas de zinco ou folhas de compensados. Fogueiras servindo de fogão para fazer o mocotó, a feijoada, o cozido, o vatapá, mas, na maioria das vezes, para fazer aquele arroz de terceira grudado, angu duro ou muito ralo, aqueles carurus catados no mato, mal lavados ou simplesmente nada. Apenas olhares carcomidos pela fome, em frente aos barracos, num desespero absoluto e que por ser absoluto é calado. [...] Os abismos têm várias faces e encantam [...] São as pessoas nesse desespero absoluto que a polícia procura, espanca com seus cacetetes possíveis e sua razão impossível, fazendo com que elas, com seus olhares carcomidos pela fome, achem plausíveis os feitos e os passos de Pequeno e de sua quadrilha pelos becos que, por terem só uma entrada, se tormam becos sem saídas, e achem, também, corriqueira essa visão de meia cara na quina do último barraco de cada beco, de crianças negras ou filhas de nordestinos, de peito sem proteção, pé no chão, shorts rasgados e olhar já cabreiro até para o próprio amigo, que, por sua vez, se tornava inimigo na disputa de um pedaço de sebo de boi achado no lixo e que aumentaria o volume da sopa, de um sanduíche quase perfeito nas imediações de uma lanchonete, de uma pipa voada, ou de um ganso dado numa partida de bola de gude" (Lins, 1997, p. 314; grifos nossos).
} 
Não há luta de classes explícita no mundo ficcional de Cidade de Deus. Em grande parte do tempo, é um matadouro de pobres, de desvalidos exterminando miseráveis, de policiais pobres matando trabalhadores e bandidos pobres. Nesse cenário, é possível até mesmo aparecer malandros com consciência etnicossocial ${ }^{15}$, soluções e conversões mágico-religiosas, intervenções externas para escapar ao matadouro ou ter poder de exterminar inimigos, como nos excertos a seguir.

Lá do Outro Lado do Rio, Marreco dormia em cima das raízes expostas da figueira mal-assombrada. À meianoite tudo no mundo parou, todo o silêncio das coisas se manifestava hiperbólico, uma fumaça vermelha saía dos ferimentos feitos pelo policial, tudo era muito escuro; agora a figueira mal-assombrada balançava ao vento que só ela recebia, os suplícios do seu corpo sumiram, assim como todas as coisas do universo. Somente a figueira vergava iluminada por uma luz que vinha subindo pelo tronco saído do próprio chão. Sobre suas folhas um homem louro e de olhos azuis, estressados, fixos nos olhos de Marreco. Completamente calado, disse, através do pensamento, todas as coisas que queria a Marreco, que ria, chorava, se encantava e se comprometia (Lins, 1997, pp. 123-24).

\footnotetext{
${ }^{15}$ Por exemplo, o personagem $O$ Grande, que entre outras coisas "[...] matava policiais por achar a raça mais filha da puta de todas as raças, essa raça que serve aos brancos, essa raça de pobre que defende o direito dos ricos. Tinha prazer em matar branco, porque o branco tinha roubado seus antepassados da África para trabalhar de graça, o branco criou a favela e botou o negro para habitá-la, o branco criou a polícia para bater, prender e matar o negro. Tudo, tudo que era bom era dos brancos. O presidente da República era branco, o médico era branco, os patrões eram brancos, o vovô-viu-a-uva do livro de leitura de escola era branco, os ricos eram brancos, as bonecas eram brancas e a porra desses crioulos que viravam polícia ou que iam para o Exército tinha mais era que morrer igual a todos os brancos do mundo" (Lins, 1997, p. 206).
} 
Tudo em Alicate se transforma em emoção ao ouvir essas palavras jubilosas [...] O cristão mudou-se, sem se despedir dos amigos, um mês depois da visita dos religiosos. Largou o baralho, canivete, o revólver, os vícios [...] Volta e meia dizia para Cleide que ele sim tinha arrebentado a boa. Conseguiu um emprego na empresa Sérgio Dourado, onde foi explorado durante muito tempo, mas não ligava. A fé afastava o sentimento de revolta diante da segregação que sofria por ser negro, desdentado, semianalfabeto. Os preconceitos sofridos partiam dessa gente que não tem Jesus no coração. Teve dois filhos com Cleide e sempre que podia voltava em Cidade de Deus para pregar o Evangelho (Lins, 1997, pp. 155-56).

- Eu sou o Diabo, moleco! Eu sou o Diabo! Se quiser eu te tiro desse buraco, esse, boto suncê num lugar formosado [...] Dadinho fechou os olhos e abaixou a cabeça. Sentia força do Exu, que não brinca porque não é de brincadeira [...] Poderia optar pelo mundo em que desejaria estar, era só escolher qual jogo queria jogar, sairia daquele buraco ou cavaria sempre mais; em qualquer jogo seria vencedor na proteção do Exu [...] Era ali que se formava verdadeiramente um destino escolhido, um destino onde não haveria dúvidas; na verdade, um destino que a vida lhe traçara e ele agora vislumbrava por entre arreios [...]. (Lins, 1997, p. 209; grifos nossos).

Quando não raro, a fé em um deus ou o pacto com um demônio falham, o que sobra é o acordo entre os homens. Um universo de favores, corrupção e permissividade se constrói em Cidade de Deus. No matadouro, a autoridade e a legitimidade estão em permanente disputa. Os acertos de vida e morte são necessários, porém, tão breves quanto as vidas em questão. Também o Estado negocia o tempo todo nesse universo. São os policiais ou membros do Exército (brigada de 
paraquedistas) ${ }^{16}$ que fornecem armas, munição, drogas etc. aos malandros e bichos-soltos.

Cabeção, Touro, Monstrinho, Lincon, Sargento Geraldo e outros matutos, como são chamados os mercadores de armas naquele universo, negociam vida e morte, na mesma moeda que os bandidos. Estão sujeitos a éticas quase semelhantes, têm as vidas tão breves quanto e compõem mais peças pobres no mosaico. "Depois de saber que o detido tinha pai e mãe, em vez de encaminhá-lo ao posto policial, obrigou-o a levá-lo à sua casa, mirando extorquir dinheiro da família. E foi o que fez" (Lins, 1997, p. 105).

Ou ainda: "O senhor pode vir aqui pegar um calaboca na hora do baile mesmo. É só não pedir documento e não prender ninguém. Pode andar pelo clube, escutar uma música, tomar um refrigerante, que tá tudo certo, mas deixa o baile correr frouxo. Valeu?” (p. 39). O acordo foi firmado, para essa e muitas outras ocasiões. E rompido sem pudor, quando assim

192 foi conveniente a uma das partes, em diferentes momentos e entre variados personagens da narrativa.

\section{0 fim e o princípio}

Chegamos ao fim retomando o princípio: se, como sugere Auerbach (1994 [1946], p. 482), o todo é "uma questão de atitude do escritor com relação à realidade do mundo que representa", não podemos deixar de observar as particularidades dessas duas realidades que implicam soluções ficcionais diversas.

Em linhas gerais, as duas narrativas se ocupam dos impasses criados por uma socialização violenta, evidenciando as noções de autoridade e poder que conformam os dois uni-

\footnotetext{
16 "O soldado paraquedista caminhou para os Blocos Velhos, onde morava. Na verdade, não queria tomar a boca de fumo do morro do São Carlos coisa nenhuma, aceitara o convite de Pequeno por medo, mas não demonstraria isso aos outros soldados. Falaria que vender fumo dava mais dinheiro do que assaltar banco e roubar carros, e também era muito menos arriscado" (Lins, 1997, p. 285).
} 
versos. Perpassado por relações pessoais, os arranjos possíveis entre autoridade e poder parecem ser, pois, uma chave explicativa importante dos textos e contextos em questão.

Se, no universo dos engenhos nordestinos, o arbítrio do senhor não está em disputa, no conjunto habitacional carioca o direito de mando é disputado por atores que ocupam posições de relativa igualdade. Se tal traço indica uma socialização moderna, não podemos deixar de observar que a modernidade, nesse contexto, implica violência.

Em Fogo morto, temos um universo marcado por relações sociais estabelecidas entre desiguais. O que se vê, então, é a autoridade virtualmente ilimitada do senhor de engenho, fundada pelo exercício do poder não apenas em seus domínios territoriais, mas, especialmente, em todas as demais esferas da vida pública.

Já em Cidade de Deus, a desigualdade de posições sociais não está fixada rigidamente; a autoridade, que não se expande para além dos limites do conjunto habitacional, é constantemente disputada, o que acaba por deslocar o lugar e o sentido da violência no mundo social e no universo narrativo.

Diferentes arranjos entre autoridade e poder forjam, pois, explicações diversas para os fracassos individuais e coletivos com os quais narradores e personagens se debatem. Se a lógica rural se desagrega porque não é mais capaz de reproduzir organicamente os papéis sociais definidores de sua socialização, não deixa de ser importante notar que a cidade em questão possui na marginalidade um forte sentido operativo, afinal, é pela margem que o narrador de Cidade de Deus tenta alinhavar os fragmentos de sua narrativa. Alinhavo que, em ambas as narrativas, é conduzido pelo fio da memória: daquilo que não pode mais ser, no caso de Fogo morto, e daquilo que poderia ter sido, no caso de Cidade de Deus.

Em Fogo morto e Cidade de Deus, não existe novidade alguma em estar vivo. O lugar social ocupado pelos grupos 
expostos na narrativa, em meio ao desenrolar de crises, de diferentes dimensões e consequências, para ambos, explicita posições que raramente se alteram.

A consciência dos significados da crise são particularmente importantes na maneira como os narradores de ambos os romances observam os processos sociais diante de seus olhos. Se existem dessemelhanças na narrativa, não é incorreto afirmar, como o faz Paulo Lins, que há alguma ressonância na construção do mundo da decadência dos engenhos - onde a autoridade dos coronéis se esfarela continuamente e ganha progressivamente ares artificiais, como no caso de Lula do Santa Fé - com o mundo da favela de Cidade de Deus, sendo que neste o processo se desenvolve nas classes baixas, com aqueles que poderiam ser netos ou bisnetos dos escravos, libertos e homens livres, trabalhadores de eito do findo ciclo da cana-de-açúcar, filhos de nordestinos migrantes.

194 Deixados à própria sorte, nas posições mais baixas em diferentes momentos e aspectos; ou se estabelecendo arranjos precários, numa vivência autoritária das soluções pelo alto: a rarefação das relações sociais descamba para uma violência legitimada por sua ilegalidade. E essa, a ilegalidade, que deveria ser exceção, se torna a regra socialmente compartilhada por diferentes setores da sociedade civil, pelo Estado, pelas classes baixas, remediadas ou privilegiadas e as relações deturpadas que se estabelecem entre todos.

Ora, a ausência de novidade em estar vivo se refere à imutabilidade de processos sociais. A crise republicana e abolicionista atinge as elites do engenho de maneira central, mas há a possibilidade de acordo e arranjo, tanto no passado do mundo rural como no presente urbano. Para as classes baixas nessa situação, no momento de transição, embora o processo seja dramático, há alguma possibilidade de integração, de devir, de fabulação social, de um horizonte de possibilidades, por mais precárias que sejam. 
No universo ficcional de Cidade de Deus, as personagens enunciam claramente a sua impossibilidade de realização social, dada por princípio e confirmada quotidianamente. "Falha a fala. Fala a bala". Não há espaço ao diálogo, somente ao enfrentamento; os acordos, quando existem, são precários e vazios. O pacto, individual, quando é possível, se estabelece com o extraterreno, acima da coletividade dos homens.

O futuro não está em aberto, não dura muito mais tempo que a trajetória de um projétil rumo a um crânio ou da decisão de passar um inimigo - seja um chefe do tráfico, um trabalhador, um estudante, um malandro, um policial, um bebê ou um desavisado. Não existe transição ou mediação: vive-se o resultado imediato da insolvência das duas crises sociopolíticas que instauram a modernidade brasileira.

Na transição do mundo antigo para sociedade liberal, como demonstrou Roberto Schwarz (2000), o favor era nossa mediação universal. No universo da experiência irresoluta da crise, a violência sistemática e quotidiana, nos seus mais diversos níveis e expressões, é o que nos nivela.

Existem personagens em Cidade de Deus que se estabelecem entre dois mundos. É o caso de Buscapé, o cocota que se torna fotógrafo, ligado a movimentos políticos, universitário. A solução de seu destino, entretanto, é individual, em meio ao fracasso da experiência coletiva. É curioso pensar que, ao final da terceira parte, após o desenrolar da batalha insana entre Zé Pequeno e Mané Galinha, o narrador nos apresenta uma espécie de balanço das perdas e ganhos. Os malandros e bicho-soltos morrem aos montes; mas não muito diferente de outros personagens mais amenos. Alguns são trânsfugas daquele inferno, como Buscapé, os Katanazaka, Angélica e outros. Mas são apenas os personagens ambivalentes e nunca de maneira articulada com o todo.

Fogo morto e Cidade de Deus são dois grandes romances que condensam aspectos importantes da nossa fracassada experiência social de modernidade. Nisso se tornam parentes. 
Violência, autoridade, poder, legitimidade e ilegalidade são categorias com as quais eles operam de maneira magistral, num tenso corpo a corpo com o texto por seus autores, procurando dar inteligibilidade ao que é cinicamente incompreensível.

\section{Mariana Miggiolaro Chaguri}

é professora do Instituto de Filosofia e Ciências Humanas da Unicamp.

\section{Mário Augusto Medeiros da Silva}

é professor do Instituto de Filosofia e Ciências Humanas da Unicamp.

\section{Bibliografia}

AMARAL, M. 2003. "Sem medo de ser" [Entrevista de Paulo Lins]. Caros Amigos, São Paulo, ano VII, n. 74, maio.

AUERBACH, E. (1994 [1946]). Mimesis. A representação da realidade na literatura ocidental. São Paulo: Perspectiva.

CANDIDO, A. 1959. O observador literário. São Paulo: Conselho Estadual de Cultura.

CHAGURI, M. M. 2012. As escritas do lugar: região e regionalismo em José Lins do Rego e Erico Verissimo. Tese de doutorado em Sociologia, Instituto de Filosofia e Ciências Humanas, Unicamp.

FONSECA, J. C. G. 2001. Entre a voz e o discurso: a dialética da bondade em Fogo morto, de José Lins do Rego. Tese de doutorado em Teoria Literária e Literatura Comparada, Faculdade de Filosofia, Letras e Ciências Humanas, USP.

GOLDMANN, L. 1956. Le Dieu caché: étude sur la vision tragique dans les Pensées de Pascal et dans le théâtre de Racine. Paris: Gallimard.

LINS, P. 1997. Cidade de Deus, São Paulo: Companhia das Letras. LINS DO REGO, J. 1997 [1943]. Fogo morto. São Paulo: Klick Editora. MELlO, J. A. 2008. "O Fogo morto em Cidade de Deus". Cultura Crítica, v. 8, pp. 30-40.

SCHWARZ, R. 1999. “Cidade de Deus” In: Sequências brasileiras. São Paulo: Companhia das Letras. 2000. Ao vencedor as batatas. 5. ed. São Paulo: Duas Cidades/

Editora 34. 
SILVA, M. A. M. 2011. A descoberta do insólito: literatura negra e literatura periférica no Brasil (1960-2000). Tese de doutorado em Sociologia, Instituto de Filosofia e Ciências Humanas, Unicamp. 2013. A descoberta do insólito: literatura negra e literatura periférica no Brasil (1960-2000). Rio de Janeiro: Aeroplano.

SILVA, M. A. M.; COSTA, K. P. 2007. Entrevista com Paulo Lins. São Paulo, 26 nov. [mimeo].

THOMPSON, F. M. 1957. "José Lins do Rego". Tribuna da Imprensa, Rio de Janeiro, n. 21/22, set.

VARGAS, L. M. B. 2009. No rastro do romance: violência institucional em Fogo morto e Cidade de Deus. Dissertação de mestrado em Cognição e Linguagem, Universidade Estadual do Norte Fluminense (UENF).

WAIZBORT, L. 2007. A passagem do três ao um. São Paulo: CosacNaï.

WILLIAMS, R. 1989. O campo e a cidade: na história e na literatura. São Paulo: Companhia das Letras. 


\section{SENTIDOS DA CRISE: LITERATURA E PROCESSOS SOCIAIS EM FOGO MORTO E CIDADE DE DEUS}

MARIANA MIGGIOLARO CHAGURI

\section{MÁRIO AUGUSTO MEDEIROS DA SILVA}

Resumo: Este artigo aproxima os romances Fogo morto (de 1943), de José Lins do Rego, e Cidade de Deus (de 1997), de Paulo Lins, explorando a hipótese de que, ao figurarem aspectos de processos de crise social, as narrativas acionem a violência como mediação privilegiada das relações entre os indivíduos e destes com o Estado. Nesses termos, os conflitos em torno da autoridade e do poder estabelecem os nexos entre forma literária e processo social, possibilitando uma análise dos limites à efetivação dos direitos sociais e, consequentemente, da afirmação da igualdade como princípio regulador da vida republicana brasileira.

Palavras-chave: Direitos e Cidadania; Sociologia da Literatura; José Lins do Rego; Paulo Lins.

\section{MEANINGS OF THE CRISIS: LITERATURE AND SOCIAL PROCESS IN TWO BRAZILIANS NOVELS, FOGO MORTO AND CIDADE DE DEUS}

Abstract: This paper approaches the novels Fogo morto (1943) by José Lins do Rego and Cidade de Deus (1997): a novel by Paulo Lins to explore the hypothesis that the narratives deals with aspects of processes of social crisis and, by doing so, trigger violence as privileged mediation of relations between these individuals and the state. Accordingly, the conflicts over authority and power establish the connections between literary form and social process, enabling to analyze the boundaries to the effectiveness of social rights and, consequently, the statement of equality as a regulatory principle of the Brazilian republican life.

Keywords: Rights and Citizenship; Sociology of Literature; José Lins do Rego; Paulo Lins. 